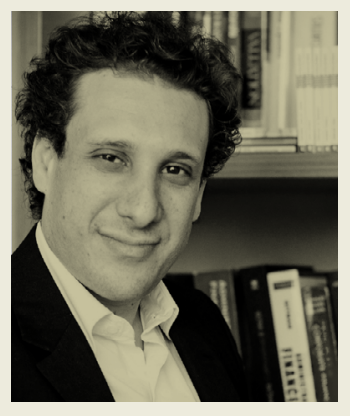

\title{
EXCESSO DE PRESSÃO NÃO FARÁ SUA EMPRESA CRESCER
}

O mundo corporativo, marcado pela competitividade, tem um lado sombrio e indesejado que está presente em boa parte das companhias: a hostilidade.

Quem já vivenciou a pressão cotidiana de bancos, multinacionais, empresas do setor financeiro em busca de melhores resultados sabe que problemas de saúde ligados ao excesso de estresse são comuns. No campo da gestão, há quem acredite que, quanto mais os funcionários são pressionados, mais estarão preparados. Essa linha de raciocínio, no entanto, tem um grave problema: não se sustenta por muito tempo.

Uma experiência vivida por Daniel Kahneman, especialista em psicologia econômica, mostra que o incentivo é mais adequado quando comparado ao tratamento hostil. Durante um treinamento com pilotos da Força Aérea Israelense, Daniel defendeu a ideia de que o estímulo poderia funcionar melhor do que a pressão excessiva, o que foi prontamente contestado por um dos instrutores mais experientes. $\mathrm{Na}$ ocasião, o oficial argumentou que quando gritava com um piloto que realizara uma manobra mal feita seu desempenho melhorava no movimento seguinte. Em contrapartida, quando o piloto executava uma bela manobra e recebia um elogio, seu desempenho posterior não era tão espetacular. No raciocínio do instrutor, a pressão deixava os pilotos mais alertas e meticulosos. Por outro lado, os elogios pareciam ter efeito contrário, deixando-os mais despreocupados.

$\mathrm{Na}$ verdade, isso é conhecido como regressão à média. Os desempenhos excelente e péssimo não passam de picos em um processo aleatório como outro qualquer. Quando um piloto se sai muito abaixo da média em uma manobra, o mais provável é que apresente um resultado melhor em seguida. O contrário acontece da mesma forma: se seu desempenho foi muito acima do normal, a tendência é que a manobra seguinte seja mais próxima da média. Sendo assim, não são elogios ou berros que determinam a qualidade da manobra; os picos de desempenho fazem parte do processo de aleatoriedade.

Todavia, o excesso de pressão no ambiente corporativo tem um efeito colateral muito forte, já que o funcionário se sente impelido a apresentar melhor desempenho. A busca por resultados positivos deve ser fruto de uma motivação maior, como o interesse de consolidar a carreira e crescer dentro da empresa. A pressão produz efeito contrário: desgasta a vontade do funcionário de se manter engajado a longo prazo e tende a transformar o trabalho em um fardo. Quando a pessoa se vê ligada ao emprego somente pela questão financeira, não encontrando prazer em sua função, tende a buscar recolocação profissional.

Além disso, a pressão contínua gera alta rotatividade, o que representa custos elevados para a organização, especialmente por conta do treinamento constante de novos funcionários. Ruim para a empresa, para os gestores e para os colaboradores.

Motivação é um dos principais ingredientes para que uma equipe se mantenha forte e trabalhe por bons resultados. O funcionário que é ouvido e possui autonomia para desenvolver suas habilidades tem muito mais vontade de continuar engajado do que aquele que só recebe ordens. Pense nisso quando estruturar sua gestão. $\mathrm{O}$ motor de seus funcionários deve ir além de um contracheque vistoso. 